Canadian University Music Review

Canadian University Music Review

Revue de musique des universités canadiennes

\title{
ALAN M. GILLMOR. Erik Satie. Boston: Twayne Publishers,
} 1988. xxvi. 387 pp.

Alan Lessem

Volume 9, numéro 1, 1988

URI : https://id.erudit.org/iderudit/1014928ar

DOI : https://doi.org/10.7202/1014928ar

Aller au sommaire du numéro

Éditeur(s)

Canadian University Music Society / Société de musique des universités

canadiennes

ISSN

0710-0353 (imprimé)

2291-2436 (numérique)

Découvrir la revue

Citer ce compte rendu

Lessem, A. (1988). Compte rendu de [ALAN M. GILLMOR. Erik Satie. Boston: Twayne Publishers, 1988. xxvi. 387 pp.] Canadian University Music Review / Revue de musique des universités canadiennes, 9(1), 202-204.

https://doi.org/10.7202/1014928ar

All Rights Reserved (C Canadian University Music Society / Société de musique des universités canadiennes, 1988
Ce document est protégé par la loi sur le droit d'auteur. L'utilisation des services d'Érudit (y compris la reproduction) est assujettie à sa politique d'utilisation que vous pouvez consulter en ligne.

https://apropos.erudit.org/fr/usagers/politique-dutilisation/ 


\section{REVIEWS/COMPTES RENDUS}

ALAN M. GILLMOR. Eric Satie. Boston: Twayne Publishers, 1988. xxvi. 387 pp.

We have long awaited a comprehensive study, in English, of the composer Erik Satie, and can now be especially pleased to see it appear from the pen of Alan Gillmor, who through his earlier doctoral research and published articles emerged as an authority on the subject. From start to finish, the book strikes an ideal balance between biography, musical description and critical evaluation. It is a pleasure to read for other reasons too: Professor Gillmor is that rarity among academics who, while in full command of all that it takes to do scholarly research, is also able to write with finesse, wit and charm.

The author takes us chronologically through the composer's life and works. While considerable attention is given to lesser compositions, about which we receive valuable new information, the core of the book is to be found in the chapters which examine, in detail, major works such as the piano suites, Parade and Socrate. From the beginning Satie is presented as the "quintessential modernist" who turned his back on much of the musical legacy, felt only contempt for those institutions and practices of his day which perpetuated that past, and resisted the tide of French Wagnerism. In composing he preferred, above all, to use a kind of shock tactic, elevating the banal and already-toofamiliar to the status of high art, that being all mixed up with a rather private brand of whimsical irony which led him ultimately to a kind of music you weren't meant to listen to anyway. Gillmor is anxious to show that the fundamental intent was to breathe fresh air into fin-de-siècle decadence, and by and large he succeeds. With Satie, "the passion for destruction is also a creative passion" (p. 263), indeed a celebration, all over again, of life itself.

The sources of Satie's style are shown to lie as much in his resistance to prevailing trends and "official" culture as anything else. There was an early immersion in a kind of nationalistic neo-medievalism, together with a pseudomysticism deriving from the Rosicrucians, and perhaps a more healthy admiration for Chabrier. The real inspiration, however, was found in childhood things, and in what he heard around him in the streets and cafés of Paris, with only the occasional idiosyncratic nod towards the "classics". As Gillmor notes, he was more drawn to poets and painters of his time, and what they stood for, than musicians. A chapter entitled "Montmartre and the Chat Noir" provides a succinct and lively description of Satie's social and cultural milieu. One is left wondering, however, whether French musical traditions were not more important to the subject than Gillmor allows. Long-spun, smoothly contoured melodies, modally inflected harmonies and a tendency toward loose metrical organization are just some of the stylistic features which Satie surely shares with 
musical predecessors. More particularly, ways of handling musical declamation in works like Socrate surely connect to long-standing French practice.

Of course, it was the composer's iconoclasm which, in the end, made him what he was, and the persistent nay-saying also manifested itself in some quite nasty personality traits: misanthropy, xenophobia, self-aggrandizement and constant posturing. We learn about his laziness and inability to learn, or apply, the essentials of compositional craft. (One may well ask to what degree his indifference to the musical past was not due to his incapacity to absorb it). But it is just here that Gillmor presents an interesting thesis: Satie "almost miraculously transformed his alleged technical incapacities into a virtue," thus "clearing the stage for a truly contemporary aesthetic" (p. x). That thesis is essential to the argument that the music cannot be examined or evaluated by traditional criteria, but requires instead its own analytical and critical framework. For the purpose, the author does not attempt to venture any new-fangled theory or method, but simply attends closely to what seems to matter in the music, describing significant stylistic features in readable prose. As a frame of reference, he uses more general ideas and concepts which are not always fully enough defined or worked out. Thus early in the book Satie is said to have achieved (with Ives) a "unique coalescence of traditionally antagonistic idioms that opens a path to the future..." (p. 18), but it doesn't ever become clear just how that "coalescence" is accomplished in either a technical or aesthetic sense. Again, an important element of the music is seen to lie in its "negation of the temporality characteristic of tonal music" (p. 82), leading Gillmor to use spatial metaphors (drawn, for example, from the vocabulary of Cubism) as the more appropriate descriptive means. Surely, however, for music of any kind there must be motion somewhere, even if not teleological like the traveller headed for home. Thus the challenge for the analyst of music such as Satie's is to come up with terms that can adequately convey just how it does move in time - the quality of that motion.

The book is illuminating in making its technical points together with observations on what is being expressed by the music. For example, we learn about the block-like construction of Parade, its "geometric shapes and interesting cubistic complexes" (p. 199), and are told too about its "air of pessimism and bitterness" (p. 200). We are not, however, told about the nature of the link between technique and expression, or indeed if there is any link at all. Granted, the whole Satie phenomenon being as essentially ambiguous as it is, there will always be difficulty in characterizing it with any degree of completeness. What one has to watch out for is a particular kind of complexity, in the man himself as much as the music, which is likely to lay traps even for the wary. When, after discussing the musique d'ameublement, the author states that "in a very real sense all the composer's music might be considered 'furniture music"' (p. 232), then we know we are in one of these traps. For the truth of the statement (if it is true) can only be paradoxical; we are dealing here with music which, as Satie insisted, isn't meant to be taken seriously at all. If what is really at issue 
here is a kind of minimal composition (we are shown, for instance, how little inclined Satie is to rework his musical source materials), then analysis as such will certainly count for less than a full description of contextual elements: musical, literary, cultural and philosophical too. And it is in this kind of description that the book shows real strength.

Throughout, emphasis is placed on Satie's historical importance for twentiethcentury music as a whole; he is considered a precursor and a seminal influence (in regard to the youth culture of the sixties, he is described as a "protohippie"). Gillmor does not worry too much about the question of historical versus critical interpretation, one that has lately been on the minds of several leading musicologists in North America and abroad. In the case of Satie, it could possibly be argued that the historical influence was greater, in the long run, than the music's instrinsic worth. Considering his importance for by now several generations of French and American composers in particular, not to mention pop musicians and the music industry at large, there is still much to be done in sorting out the reception of the music and its underlying ideas. Gillmor cannot be faulted for making only a few closing observations in that regard, since his central purpose is to provide a critical study of the music itself, seen in its full context. And with this, the book, thoroughly researched and intelligently organized as it is, does a very good job. All Satie research to come will use it as a valuable resource, indeed an indispensable point of departure. It comes with an extensive bibliography, catalog of musical works, and discography.

Alan Lessem

ARTURO PENÓN et JAVIER GARCÍA MÉNDEZ. Le Bandonéon depuis le Tango, Montréal, Les Éditions du COATL, 1986 (réimpression : Montréal, VLB éditeur, 1987), $71 \mathrm{p}$. en français et $71 \mathrm{p}$. en espagnol.

Le Bandonéon depuis le tango raconte la longue vie d'un instrument qui est toujours animé du même souffle. Ce récit, évoquant odeurs, couleurs et sentiments, nous présente le bandonéon comme un personnage typique et unique de la vie portuaire de Buenos Aires. Dans ce récit-biographie, le bandonéon - comme l'homme au sein de la societé - vit des moments de fusion et de confusion lors de son équipée argentine. Sa naissance obscure en Allemagne et les nombreuses controverses qu'il a soulevées, son arrivée discrète à Buenos Aires, sa popularité croissante en milieu ouvrier, ses années de gloire avec les plus grands musiciens, compositeurs, arrangeurs et interprètes, ses tournées dans le monde et, enfin, ses moments plus solitaires sont racontés par Arturo Penón et Javier García Méndez. Le premier, musicien interprète argentin réputé, l'a transporté et caressé pendant ces cinquante dernières années; l'autre, critique littéraire uruguayen bien connu, l'a admiré et écouté d'aussi loin qu'il puisse se souvenir. 